\title{
PENGARUH KEADILAN ORGANISASI DAN SISTEM \\ PENGENDALIAN INTERN TERHADAP KECURANGAN \\ (STUDI KASUS PADA PT. BANK MANDIRI)
}

Oleh :

Tagor Darius Sidauruk, SE, M.Si

dan

Intan Febriyanti

\section{Fakultas Ekonomi Program Studi Akuntansi \\ Universitas Satya Negara Indonesia}

\begin{abstract}
ABSTAK
Penelitian ini bertujuan untuk mengetahui adakah pengaruh keadilan organisasi dan pengaruh sistem pengendalian terhadap kecurangan pada karyawan PT. Bank Mandiri di wilayah Jakarta Pusat.

Penelitian ini memakai metode kausal dengan unit analisis yang diteliti adalah karyawan yang bekerja pada Bank. Jumlah sampel yang dipakai untuk pengujian sebanyak 39 responden. Uji yang dipakai adalah regresi linier berganda.

Berdasarkan pengujian yang telah dilakukan, pada variabel keadilan organisasi tidak memiliki pengaruh yang signifikan pada kecurangan dan pada variabel sistem pengendalian terdapat pengaruh yang signifikan terhadap kecurangan.
\end{abstract}

Kata Kunci : Keadilan Organisasi, Sistem Pengendalian Intern, Kecurangan 


\section{PENDAHULUAN \\ Latar Belakang}

Masyarakat pada zaman sekarang menyimpan uang mereka di bank, karena selain aman banyak juga manfaat lainnya yang bisa masyarakat rasakan. Banyaknya perusahaan bank yang sekarang menawarkan keuntungan yang menarik bagi nasabahnya, baik itu dari bank milik BUMN maupun bank swasta lainnya. Banyak juga program yang ditawarkan oleh pihak bank kepada masyarakat, sehingga masyarakat lebih mudah memilih sesuai dengan kebutuhan mereka. Semakin banyak nasabah berarti bank tersebut berarti semakin banyak nasabah yang mempercayai harta mereka untuk disimpan di bank tersebut. Kepercayaan masyarakat merupakan faktor utama bisnis perbankan, sehingga manajemen bank harus berupaya untuk menjaga dan mempertahankan kepercayaan tersebut. Salah satunya adalah dengan cara mentaati peraturan dan tidak melakukan kesalahan yang dapat menyebabkan terjadinya penyimpangan dan kecurangan.

Sebagai pusat perputaran keuangan, yang berasal dari dunia usaha maupun kegiatan publik, Perbankan sangat rentan terhadap penyalahgunaan kewenangan ataupun tindakan kecurangan. Empat faktor pendorong seorang melakukan kecurangan yaitu: greed (keserakahan), opportunity (kesempatan), need (kebutuhan) dan exposure (pengungkapan).

Keadilan organisasi merupakan istilah untuk mendeskripsikan keadilan ditempat kerja. Keadilan organisasi menekankan bagaiman reward, insentif, pengakuan, pekerjaan, dan sanksi dalam satu lembaga/perusahaan dialokasikan secara adil dan proporsional. Bila keadilan pada karyawan terpenuhi dengan baik maka produktivitas dan hasil kerja karyawan akan meningkat dan menghilangkan motivasi untuk melakukan tindakan yang merugikan perusahaan.

Sistem pengendalian intern yang efektif merupakan komponen penting dalam manajemen bank dan menjadi dasar kegiatan operasional bank yang sehat dan aman, membantu pengurus menjaga aset bank, menjamin tersedianya pelaporan keuangan dan manajerial yang dapat dipercaya, meningkatkan kepatuhan bank terhadap ketentuan dan peraturan yang berlaku, serta mengurangi risiko terjadinya kerugian, penyimpangan dan pelanggaran aspek kehati-hatian.

Berdasarkan uraian diatas, peneliti tertarik untuk melakukan penelitian pada PT. Bank Mandiri, dengan judul penelitian yang dipilih adalah :

\section{"Pengaruh Keadilan Organisasi dan Sistem Pengendalian Intern terhadap Kecurangan".}

\section{Perumusan Masalah}

Berdasarkan uraian diatas, maka penulis dapat perumusan masalah yang akan diteliti sebagai berikut:

1. Apakah keadilan organisasi berpengaruh terhadap kecurangan?

2. Apakah sistem pengendalian intern berpengaruh terhadap kecurangan? 


\section{Tujuan dan Kegunaan Penelitian \\ Tujuan penelitian}

Berdasarkan rumusan masalah diatas, maka tujuan yang ingin dicapai dalam penelitian ini adalah :

1. Untuk mengetahui pengearuh keadilan organisasi terhadap kecurangan.

2. Untuk mengetahui pengaruh sistem pengendalian intern terhadap kecurangan.

\section{Kegunaan Penelitian}

a. Sebagai sarana bagi penulis untuk mengembangkan dan meningkatkan ilmu pengetahuan yang diperoleh dari bangku perkuliahan yang ada didalam dunia kerja.

b. Dapat memberi informasi tambahan bagi para pembaca yang ingin menambah dan memperoleh ilmu pengetahuan.

c. Bagi calon peneliti, hasil penelitian ini diharapkan digunakan sebagai referensi, sumbangan pemikiran dan dasar penelitian lebih lanjut terkait dengan tema penelitian ini.

\section{LANDASAN TEORI \\ Keadilan Organisasi}

Pengertian keadilan secara umum adalah hal-hal yang berkenaan pada sikap dan tindakan dalam hubungan antar manusia yang berisi sebuah tuntutan agar sesamanya dapat memperlakukan sesuai hak dan kewajibannya. Macam-macam keadilan secara umum adalah keadilan komunikatif, keadilan distributif, keadilan legal, keadilan vindikatif, keadilan kreatif, keadilan protektif.

Organisasi adalah sistem saling pengaruh-mempengaruhi antara orang dalam kelompok kerjasama untuk mencapai suatu tujuan tertentu yang sama. Tujuan organisasi secara keseluruhan tidak mungkin dijalankan oleh seorang tertentu saja. Untuk mencapai tujuan organisasi, manajemen selain mempunyai dua fungsi utama yaitu perencanaan (planning) dan pengendalian (controlling), juga mempunyai funngsifungsi yang lain, yaitu organizing, staffing dan leading.

Keadilan organisasi adalah persepsi perlakuan adil yang didapat oleh pegawai dari organisasi. Keadilan organisasi terdiri dari tiga tipe, yaitu : (1) keadilan distributif, (2) keadilan prosedural, dan (3) keadilan interaksional. Keadilan distributuf adalah keadilan yang diterima seseorang sebagai hasil dari keputusan managemen dalam hal pembagian alokasi sumber-sumber day, yang meliputi tiga hal: (a) Terletak pada nilai, (b) Terletak pada perumusan nilai-nilai menjadi sebuah peraturan, (c) Terletak pada implementasi peraturan. Keadilan prosedural adalah keadilan yang dipersepsikan tehadap suatu proses untuk membagi sumber daya atau alokasi. Keadilan interaksional sebagai keadilan tentang perlakuan interaksional pembuat keputusan (decision maker). Terhadap bawahan atau karyawan ketika mengimplementasikan prosedur pembagian sumber daya. Tiga hal penting yang harus diperhatikan adalah penghargaan, netralitas, kepercayaan.

\section{Sistem Pengendalian Intern}

Pengendalian intern berkaitan dengan proses-proses dan praktik dengan mana manajemen suatu organisasi berusaha untuk memastikan bahwa keputusan-keputusan dan aktivitas-aktivitas yang disetujui benar-benar diambil dan dilaksanakan. Pengendalian internal adalah rencana organisasi dan metode yang digunakan untuk 
menjaga dan melindungi aset, menghasilkan informasi yang akurat dan dapat dipercaya, memperbaiki efisiensi dan untuk mendorong ditaatinya kebijakan manajemen.

Laporan COSO mengidentifikasi lima komponen pengendalian internal yang saling berkaitan: (1) lingkungan pengendalian, (2) penentuan risiko, (3) aktivitas pengendalian, (4) informasi dan komunikasi, (5) pengawasan. Lingkungan pengendalian menciptakan suasana pengendalian dalam suatu organisasi dan mempengaruhi kesadaran personel organisasi tentang pengendalian. Penaksiran atau penentuan resiko untuk tujuan pelaporan keuangan adalah identifikasi, analisis dan pengelolaan resiko entitas yang berkaitan dengan penyusunan laporan keuangan, sesuai dengan prinsip akuntansi berterima umum di Indonesia. Aktivitas pengendalian adalah kebijakan dan prosedur yang dikembangkan oleh organisasi untuk menghadapi risiko. Aktivitas pengendalian meliputi: penelaahaan kinerja, pemisahan tugas, pengendalian aplikasi, pengendalian umum. Komunikasi mencakup penyampaian informasi kepada semua personel yang terlibat dalam pelaporan keuangan tentang bagaimana aktivitas mereka berkaitan dengan pekerjaan orang lain, baik yang berada di dalam maupun di luar organisasi. Pemantauan atau pemonitoring adalah proses penilaian kualitas kinerja pengendalian intern sepanjang waktu.

Pengendalian intern setiap entitas memiliki keterbatasan bawaan. Oleh karena itu, pengendalian intern hanya memberikan keyakinan memadai, bukan mutlak. Kepada manajemen dan dewan komisaris tentang pencapaian tujuan entitas. Berikut ini adalah keterbatasan bawaan yang melekat dalam setiap pengendalian intern: (a) kesalahan dalam pertimbangan. (b) Gangguan. Gangguan dalam pengendalian yang ditetapkan dapat terjadi karena personel secara keliru memahami perintah atau membuat kesalahan karena kelalaian. (c) Kolusi. Tindakan bersama beberapa individu untuk tujuan kejahatan. (d) Pengabaian oleh manajemen. Manajemen dapat mengabaikan kebijakan yang telah ditetapkan untuk tujuan yang tidak sah seperti keuntungan pribadi manajer. (e) Biaya lawan manfaat. Biaya yang diperlukan untuk mengoperasikan pengendalian intern tidak boleh melebihi manfaat yang diharapkan dari pengendalian intern tersebut.

\section{Kecurangan (Fraud)}

Kecurangan merupakan istilah yang umum, dan mencakup segala macam cara yang dapat digunakan dengan kelihaian tertentu, yang dipilih oleh seorang individu, untuk mendapatkan keuntungan dari pihak lain dengan melakukan representase yang salah. Kecurangan berbeda dengan kesalahan yang tidak disengaja. Kecurangan melibatkan semua cara yang dapat digunakan untuk melakukan penipuan dengan tujuan agar seseorang mendapatkan keuntungan yang lebih dari orang lain melalui representase yang salah.

Kecurangan laporan keuangan biasanya seringkali terjadi pada perusahaan yang menderita rugi atau perusahaan yang keuntungannya lebih rendah dari yang diekspektasikan. Para eksekutif biasanya melakukan kecurangan 'atas nama organisasi' yang ditujukan agar laporan keuangan yang mereka buat terlihat lebih baik dari keadaan yang sebenarnya. Para eksekutif perusahaan diuntungkan karena harga saham perusahaan meningkat atau tetap tinggi dan korban dari kecurangan tersebut adalah para investor. Dalam kecurangan pegawai, yang menjadi korban adalah organisasi tempat pegawai tersebut bekerja.

Kecurangan yang berhubungan dengan jabatan atau yang disebut dengan occupational fraud, oleh ACFE didefenisikan sebagai penggunaan suatu jabatan oleh seseorang untuk memperkaya dirinya melalui penyalagunaan yang disengaja atau 
penyalagunaan penggunaan aset atau sumber daya organisasi. Occupational fraud dapat berupa apa pun, mulai dari penyalagunaan jam istirahat makan siang hingga skema berteknologi tinggi. ACFE mengklasifikasikan occupational fraud dalam tiga kategori: (1) kecurangan aset, berupa pencurian dan penyalagunaan aset organisasi. (2) korupsi. (3) laporan yang berisi kecurangan, biasanya berupa pemalsuan laporan keuangan suatu organisasi. Kecurangan pegawai merupakan jenis occupational fraud yang paling umum. Para pegawai melakukan penipuan terhadap pemilik perusahaan tempat mereka bekerja dengan cara mengambil aset perusahaan. Kecurangan dapat terjadi secara langsung maupun tidak langsung. Kecurangan secara langsung terjadi ketika pegawai mencuri kas perusahaan, persediaan, peralatan, dan aset lainnya. Kecurangan tidak langsung terjadi ketika pegawai menerima suap atau kickback dari pemasok, pelanggan, atau pihak di luar perusahaan untuk kemungkinan memberikan harga jual yang lebih rendah, harga beli yang lebih tinggi, barang-barang yang tidak pernah sampai tujuan, atau barang-barang yang kualitasnya lebih rendah.

\section{Penelitian Terdahulu}

Dari penelitian terdahulu yang dilakukan oleh Lisa Amelia Herman (2013) memberikan hasil, yaitu bahwa keadilan organisasi secara signifikan berpengaruh negatif terhadap kecurangan, dan sistem pengendalian intern mempunyai pengaruh signifikan negatif terhadap kecurangan. Hal ini berarti bahwa sistem pengendalian intern memiliki pengaruh yang besar terhadap perusahaan.

\section{Hipotesis}

Pengujian hipotesis bertujuan untuk mengetahui pengaruh keadilan organisasi dan sistem pengendalian intern terhadap kecurangan. Adapun pengujian yang akan diuji sebagai berikut :

Ho1: diduga tidak terdapat pengaruh keadilan organisasi terhadap kecurangan.

Ha1: diduga terdapat pengaruh keadilan organisasi terhadap kecurangan.

Ho2: diduga tidak terdapat pengaruh sistem pengendalian intern terhadap kecurangan.

Ha2: diduga terdapat pengaruh sistem pengendalian intern terhadap kecurangan.

\section{METODOLOGI PENELITIAN}

\section{Waktu dan tempat penelitian}

Penelitian ini dilakukan selama 4 bulan pada PT. Bank Mandiri yang berlokasi di Jalan Tanah Abang Timur No.2, Gambir, Jakarta.

\section{Desain penelitian}

Desain penelitian yang digunakan adalah peneliti kausal (Causal Research) yang merupakan penelitian untuk mengetahui pengaruh antara satu atau lebih dari variabel bebas (Independent Variabel) terhadap variabel terikat (Dependent Variabel).

\section{Variabel penelitian}

Variabel yang digunakan dalam penelitian ini terdiri dari variabel independen (variable bebas) yaitu keadilan organisasi dan sistem pengendalian intern, dan variabel dependen (variable terikat) yaitu kecurangan. 


\section{Jenis data}

Dalam penelitian ini, peneliti menggunakan data primer untuk mengukur variabel bebas dan variabel terikat yang diambil dari individu atau perseorangan, seperti hasil wawancara atau hasil pengisian kuesioner.

\section{Populasi dan sampel}

Dalam penelitian ini, populasi yang diambil adalah karyawan yang bekerja pada PT. Bank Mandiri di Wilayah Jakarta. Sampel dalam penelitian ini diambil dengan menggunakan metode Purposive Sampling yaitu merupakan teknik pengambilan sampel yang didasarkan atas pertimbangan-pertimbangan tertentu dari peneliti. Sampel yang digunakan adalah (a) Bagian audit internal, bagian finance, bagian manajemen, dan bagian HRD. (b) Telah bekerja minimal 1 tahun.

\section{Skala pengukuran}

Skala yang digunakan adalah skala likert lima poin dengan rentang angka 1-5 yang memberikan gambaran sampai seberapa jauh responden melaksanakan fungsi sesuai dengan pernyataan yang diberikan. Skor atas pilihan jawaban untuk kuesioner yang diajukan adalah sebagai berikut : (a) $1=$ Selalu. (b) $2=$ Sering. (c) $3=$ Kadangkadang. (d) $4=$ Jarang. (e) $5=$ Tidak Pernah.

\section{Metode pengumpulan data}

Ada dua metode pengumpulan data: (1) Metode Penelitian Lapangan (Field Research) adalah metode dengan mengunjungi objek penelitian guna memperoleh datadata yang digunakan untuk penyusunan penelitian tersebut. (2) Metode penelitian kepustakaan (Library Research) adalah penelitian dengan cara mengumpulkan data dengan cara membaca dan mempelajari buku-buku yang ada dan sumber data yang lainnya berkaitan dengan pembahasan masalah yang dibutuhkan.

Teknik pengumpulan data dilakukan dengan metode angket, yaitu teknik mengumpulkan data dengan cara menyebarkan kuesioner yang berisi daftar pertanyaan terhadap responden. Angket yang digunakan adalah angket tertutup, sehingga responden hanya perlu memilih pilihan jawaban yang dianggap paling sesuai. Instrumen yang digunakan dalam penelitian ini berupa kuesioner yang akan disebarkan kepada karyawan.

\section{Metode Analisis Data}

\section{Uji kualitas data (Uji instrument)}

Hasil penelitian uji kualitas data atas data primer ini, maka peneliti menggunakan uji validitas dan realibitas.

\section{Uji validitas}

Menurut (Imam Ghozali, 2005:45), uji validitas digunakan untuk mengukur sah atau valid tidaknya suatu kuesioner. Suatu kuesioner dikatakan valid jika pertanyaan pada kuesioner mampu mengungkapkan sesuatu yang akan diukur oleh kuesioner tersebut. Pengujian menggunakan uji dua sisi dengan taraf signifikansi 0.05. Kriteria pengujian adalah sebagai berikut: (1) Jika $r$ hitung $\geq r$ table, maka butir atau pertanyaan atau indikator tersebut dinyatakan valid. (2) Jika $r$ hitung $\leq r$ table maka butir pertanyaan atau indikator tersebut dinyatakan tidak valid. 


\section{Uji reliabilitas}

Suatu kuesioner dikatakan reliabel atau handal jika jawaban seseorang terhadap pernyataan tersebut konsisten atau stabil dari waktu ke waktu. Suatu variabel dikatakan reliabel jika memberikan nilai Cronbach Alpha $>0,60$. Sedangkan jika sebaliknya data tersebut dikatakan tidak reliabel.

\section{Uji Asumsi Klasik}

\section{a. Uji Normalitas}

Menurut Imam Ghozali (2005:110), uji normalitas bertujuan untuk menguji apakah dalam model regresi, variabel pengganggu atau residual memiliki distribusi normal. Selanjutnya pengujian dilanjutkan dengan uji statistik non-parametrik One Sample Kolmogrov - Smirnov (K-S). Adapun kriteria pengujian adalah : (1). Ha = Data residual tidak berdistribusi normal, (2). Ho = Data residual berdistribusi normal.

Apabila nilai signifikasi Kolmogrov - Smirnov adalah lebih kecil dari 0,05 maka Ha diterima, sehingga data residual tidak berdistribusi normal. Sebaliknya apabila nilai signifikasi Kolmogorov - Smirnov adalah lebih besar dari 0,50 maka Ha ditolak, sehingga dari residual berdistribusi normal (Imam Ghozali, 2005 : 114). (2) Jika angka tolerance diatas angka 0,10 dan VIF $<10$ dikatakan tidak terdapat gejala multikolinearitas.

\section{b. Uji Heterokedastisitas}

Uji heterokedastisitas bertujuan untuk menguji apakah dalam model regresi terjadi ketidaksamaan varian dari residual satu pengamatan ke pengamatan yang lain. Jika varian dari residual satu pengamatan ke pengamatan yang lain tetap, maka disebut homoskedastisitas dan jika berbeda disebut heterokedastisitas. Model regresi yang baik adalah yang homoskedastisitas atau tidak terjadi heterokedastisitas. Untuk melihat ada tidaknya heterokedastisitas adalah dengan melihat grafik scalterplot antara nilai prediksi variable terikat (dependent) yaitu ZPRED dengan residualnya SRESID. Dimana sumbu $\mathrm{Y}$ adalah $\mathrm{Y}$ yang telah diprediksi dan sumbu $\mathrm{X}$ adalah residual $\mathrm{Y}$ (Y prediksi - $\mathrm{Y}$ sesungguhnya) yang telah di-studentized. Dasar analisis ini adalah (Imam Ghozali,2005:105).

1. Jika ada pola tertentu, seperti titik-titik (point-point) yang ada membentuk suatu pola tertentu yang teratur (bergelombang, melebar kemudian menyempit), maka telah terjadi heterokedastisitas.

2. Jika tidak ada pola yang jelas, serta titik-titik menyebar di atas dan di bawah angka 0 pada sumbu Y, maka tidak terjadi heterokedastisitas.

\section{c. Uji Auto Korelasi}

Uji auto korelasi bertujuan menguji apakah dalam model regresi linear ada korelasi antara kesalahan penggangu pada periode $t$ dengan kesalahan penggangu pada periode t-1 (sebelumnya). Jika terjadi korelasi, maka dinamakan ada problem autokorelasi. Auto korelasi muncul karena observasi yang berurutan sepanjang waktu berkait satu sama lainnya (Imam Ghozali, 2005:95). Mendeteksi ada atau tidaknya autokorelasi dapat digunakan uji Durbin - Watson ( $D W$ test) dengan ketentuan sebagai berikut : Jika d lebih kecil dari dL atau lebih besar dari (4-dL) maka hipotesis nol ditolak, yang berarti terdapat autokorelasi. 
i. Jika d terletak antara dU dan (4-dU), maka hipotesis nol diterima, yang berarti tidak ada autokorelasi.

ii. Jika d terletak antara dL dan dU atau diantara (4-dU) dan (4-dL), maka tidak menghasilkan kesimpulan yang pasti.

\section{Analisis Regresi Berganda}

Hipotesis dalam penelitian ini diuji dengan menggunakan metode regresi berganda. Variabel independen terdiri dari keadilan organisasi dan sistem pengendalian intern, sedangkan variabel dependen adalah kecurangan. Rumus regresi berganda yang digunakan adalah sebagai berikut :

$\mathrm{Y}=\alpha+\beta 1 \mathrm{X} 1+\beta 2 \mathrm{X} 2+\varepsilon$

Keterangan :

Y : Kecurangan

A : Konstanta

$\beta 1, \beta 2$ : Koefisien Regresi

$\mathrm{X} 1$ : Keadilan Organisasi

$\mathrm{X} 2$ : Sistem Pengendalian Intern

$\varepsilon$ : Kesalahan Pengganggu (error term)

\section{Uji Hipotesis}

Pengujian hipotesis adalah sebuah prosedur penelitian yang digunakan untuk menentukan apakah hipotesis yang diajukan berupa pernyataan dapat diterima atau ditolak.

Rancangan pengujian hipotesis dalam penelitian ini sebagai berikut :

Ho : tidak terdapat pengaruh antara variabel yang diuji (X1. X2, Y)

$\mathrm{Ha}$ : terdapat pengaruh antara variabel yang diuji $(\mathrm{X} 1, \mathrm{X} 2, \mathrm{y})$

\section{Uji Regresi Parsial (Uji-t)}

Uji t digunakan untuk mengetahui pengaruh masing - masing variabel bebas terhadap variabel terikat. Uji $t$ tersebut dapat dilihat dari besarnya probabilitas value ( $p$ value) dibandingkan dengan 0,05 . Adapun kriteria pengujian yang digunakan adalah :

Jika $\mathrm{p}$ value $<0,05$ maka Ho ditolak

Jika $\mathrm{p}$ value $>0,05$ maka Ho diterima

\section{ANALISA HASIL DAN PEMBAHASAN \\ Deskriptif Data}

1. Hasil Kuesioner yang Disebar. Kuesioner yang disebar sebanyak 50 kuesioner, namun kuesioner yang kembali sebanyak 39 kuesioner, sementara yang tidak kembali sebanyak 11 kuesioner. Dengan menggunakan 39 kuesioner yang kembali, peneliti menyimpulkan bahwa kuesioner tersebut telah layak untuk diolah dan untuk selanjutnya dilakukan penelitian.

2. Profil Responden Berdasarkan jenis Kelamin. Berdasarkan jenis kelamin peneliti membagi menjadi dua kategori, yaitu laki-laki dan perempuan. Berdasarkan hasil pengolahan data, dapat diketahui bahwa 21 responden adalah pria, dan sisanya 18 responden adalah wanita. Secara umum karyawan yang bekerja pada Bank X ini adalah berjenis kelamin pria. 
3. Profil Responden Berdasarkan Usia. Berdasarkan usia, peneliti membagi menjadi 4 kategori, yaitu: (1) usia 21-25 tahun, (2) usia 26-30 tahun, (3) usia 31-35 tahun, dan (4) usia 36-40 tahun. Berdasarkan hasil pengolahan data yang dilakukan, diketahui bahwa 20 responden berusia 20-25 tahun, 16 responden berusia 26-30 tahun, 1 responden erusia 31-35 tahun dan 2 responden berusia 36-40 tahun. Secara umum karyawan yang bekerja pada Bank X ini adalah berusia 20-25 tahun.

4. Profil Responden Berdasarkan Pendidikan. Peneliti membagi kategori ini dalam empat bagian gelar akademik tertinggi yang dimiliki oleh responden, yaitu : (1) SMA, (2) D3, (3) Strata 1, (4) Strata 2 dan lainnya. Berdasarkan hasil pengolahan data, terlihat bahwa tidak ada responden yang memiliki tingkat pendidikan SMA, 4 responden memiliki gelar D3, 32 responden memiliki gelar S1, 3 responden memiliki gelar S2 dan tidak ada responden yang memiliki tingkat pendidikan lainnya. Secara umum karyawan yang bekerja pada Bank X ini memiliki gelar akademik Strata 1.

5. Profil Responden Berdasarkan Lama Bekerja. Berdasarkan masa kerja karyawan, peneliti membagi menjadi 3 kategori, yaitu : (1) $<5$ tahun, (2) 5-10 tahun, dan (3) dan $>10$ tahun. Dari hasil pengolahan data yang dilakukan, diketahui bahwa terdapat 26 responden memiliki masa kerja $<5$ tahun, 11 responden memiliki masa kerja 5-10 tahun dan 2 responden memiliki masa kerja $>10$ tahun. Secara umum karyawan yang bekerja pada Bank $\mathrm{X}$ ini memiliki masa kerja $<5$ tahun.

6. Profil Responden Berdasarkan Jabatan. Berdasarkan jabatan pada Bank X, peneliti membagi menjadi 4 kategori, yaitu : auditor, finance, manager, supervisor. Dari hasil pengolahan yang dilakukan, bahwa tidak ada responden yang memiliki jabatan sebagai auditor, 16 responden atau $41 \%$ memiliki jabatan pelaksana learning manager, 15 responden atau 38.5\% memiliki jabatan finance dan 8 responden atau $20.5 \%$ memiliki jabatan supervisor. Secara umum rata-rata responden memiliki jabatan pelaksana learning manager.

\section{Pengujian Instrumen Penelitian \\ Uji Reliabilitas}

Suatu variabel dikatakan reliabel jika memberikan nilai Cronbach Alpha> 0,60. Sedangkan jika sebaliknya data tersebut dikatakan tidak reliabel (Nunnally, 1967).

\section{Uji reliabilitas variabel keadilan organisasi (X1)}

Berdasarkan tabel 4.1. di bawah, menunjukkan Cronbach's Alpha $0.733 \geq 0.60$. Dapat disimpulkan bahwa pernyataan-pernyataan dalam variabel keadilan organisasi adalah reliabel.

Tabel 4.1.

Uji reabilitas variabel keadilan organisasi

\begin{tabular}{|c|c|c|}
\hline $\begin{array}{c}\text { Cronbach's } \\
\text { Alpha }\end{array}$ & $\begin{array}{l}\text { Cronbach's } \\
\text { Alpha Based } \\
\text { on } \\
\text { Standardized } \\
\text { Items }\end{array}$ & $\begin{array}{l}\mathrm{N} \text { of } \\
\text { Items }\end{array}$ \\
\hline, 733 &, 737 & 9 \\
\hline
\end{tabular}

Sumber : Output SPSS 


\section{Uji reliabilitas variabel sistem pengendalian intern (X2)}

Berdasarkan tabel 4.2. di bawah, menunjukkan Cronbach's Alpha $0.684 \geq 0.60$. Dapat disimpulkan pernyataan-pernyataan dalam variabel sistem pengendalian intern adalah reliabel.

Tabel 4.2.

Uji reabilitas variabel sistem pengendalian intern

\begin{tabular}{|c|c|c|}
\hline $\begin{array}{c}\text { Cronbach's } \\
\text { Alpha }\end{array}$ & $\begin{array}{l}\text { Cronbach's } \\
\text { Alpha Based } \\
\text { on } \\
\text { Standardized } \\
\text { Items }\end{array}$ & $\begin{array}{l}\mathrm{N} \text { of } \\
\text { Items }\end{array}$ \\
\hline 684 & 711 & 9 \\
\hline
\end{tabular}

Sumber : Output SPSS

\section{Uji reliabilitas variabel kecurangan (Y)}

Berdasarkan tabel 4.3. di bawah, menunjukkan Cronbach's Alpha $0.728 \geq 0.60$. Dapat disimpulkan pernyataan-pernyataan dalam variabel kecurangan adalah reliabel.

\section{Tabel 4.3.}

Uji reabilitas variabel keadilan organisasi

\begin{tabular}{|c|c|c|}
\hline $\begin{array}{c}\text { Cronbach's } \\
\text { Alpha }\end{array}$ & $\begin{array}{l}\text { Cronbach's } \\
\text { Alpha Based } \\
\text { on } \\
\text { Standardized } \\
\text { Items }\end{array}$ & $\begin{array}{l}\mathrm{N} \text { of } \\
\text { Items }\end{array}$ \\
\hline, 728 &, 776 & 9 \\
\hline
\end{tabular}

Sumber : Output SPSS

\section{Uji Validitas}

Uji validitas ini dilakukan dengan membandingkan nilai $r_{\text {hitung }}$ dengan rtabel untuk degree of freedom $(\mathrm{df})=\mathrm{n}-2$. Dalam penelitian ini $\mathrm{df}=39-2$ atau $\mathrm{df}=37$ dengan $\alpha 0,05$ didapat $r_{\text {tabel }}$ sebesar 0,316. Apabila $r_{\text {hitung }}>r_{\text {tabel }}$ dapat disimpulkan instrumen tersebut dianggap valid

\section{Uji validitas variabel keadilan organisasi (X1)}

Berdasarkan hasil pengolahan, $\mathrm{r}_{\text {hitung }}$ (kolom Corrected Item Total Correlation) untuk masing-masing pernyataan nilainya $>$ dari $r_{\text {tabel }} 0.316$ sehingga dapat disimpulkan bahwa 9 pernyataan untuk variabel Keadilan Organisasi adalah valid.

\section{Uji validitas sistem pengendalian intern (X2)}

Berdasarkan hasil pengolahan, $\mathrm{r}_{\text {hitung }}$ untuk masing-masing butir item pernyataan nilainya lebih besar dari $r_{\text {tabel }} 0,316$, sehingga dapat disimpulkan seluruh pernyataan untuk variabel sistem pengendalian intern adalah valid. 


\section{Uji Validitas Variabel Kecurangan (Y)}

Berdasarkan hasil pengolahan, pada kolom Corrected Item Total Correlation $\left(r_{\text {hitung }}\right)$ untuk masing-masing pernyataan nilainya $>$ dari $r_{\text {tabel }} 0.316$ sehingga dapat disimpulkan bahwa 9 pernyataan untuk variabel Kecurangan adalah valid.

\section{Uji Asumsi Klasik}

\section{Uji Normalitas}

Model regresi yang baik adalah memiliki distribusi data normal atau mendekati normal, normalitas dapat diketahui denga melihat tabel One-Sample Kolmogorov - Smirnov Test pada kolom Asymp Sig (2-tailed) yaitu jika p value (sig) > 0,05 maka dapat disimpulkan bahwa data diambil dari populasi terdistribusi normal. Berikut ini adalah hasil Output SPSS untuk uji normalitas data:

Tabel 4.5.

One-Sample Kolmogorov-Smirnov Test

\begin{tabular}{|c|c|c|c|c|}
\hline & & $\begin{array}{c}\text { Keadilan_Organi } \\
\text { sasi }\end{array}$ & $\begin{array}{c}\text { Sistem_- } \\
\text { Pengendalian_In } \\
\mathrm{t} \\
\text { ern }\end{array}$ & $\begin{array}{l}\text { Kecurang } \\
\text { an }\end{array}$ \\
\hline \multicolumn{2}{|l|}{$\bar{N}$} & 39 & 39 & \\
\hline \multirow{3}{*}{$\begin{array}{l}\text { Normal } \\
\text { Parameters } \\
\text { a,b }\end{array}$} & Mean & 32.10 & 35.28 & 21.18 \\
\hline & Std. & & & \\
\hline & $\begin{array}{l}\text { Deviati } \\
\text { on }\end{array}$ & 5.020 & 3.308 & 4.316 \\
\hline \multirow{3}{*}{$\begin{array}{l}\text { Most } \\
\text { Extreme } \\
\text { Difference } \\
\text { s }\end{array}$} & $\begin{array}{l}\text { Absolu } \\
\text { te }\end{array}$ & .124 & .107 & .110 \\
\hline & $\begin{array}{l}\text { Positiv } \\
\text { e }\end{array}$ & .124 & .103 & .074 \\
\hline & $\begin{array}{l}\text { Negati } \\
\text { ve }\end{array}$ & -.086 & -.107 & -.110 \\
\hline \multicolumn{2}{|c|}{$\begin{array}{l}\text { Kolmogrov-Smirnov } \\
\mathrm{Z}\end{array}$} & .124 & .107 & .110 \\
\hline \multicolumn{2}{|c|}{$\begin{array}{l}\text { Asymp. Sig. (2- } \\
\text { tailed) }\end{array}$} & $.136^{\mathrm{c}}$ & $.200^{\mathrm{c}, \mathrm{d}}$ & $.200^{\mathrm{c}, \mathrm{d}}$ \\
\hline
\end{tabular}

a. Test distribution is Normal.

b. Calculated from data.

Dari tabel 4.5 diperoleh hasil Asymp. Sig. (2-tailed) untuk variabel keadilan organisasi $(\mathrm{X} 1)=0.136>0.05$, sistem pengendalian intern $(\mathrm{X} 2) 0.200>0.05$ dan kecurangan $(\mathrm{Y})=0.200>0.05$, maka dapat disimpulkan data yang diambil dari populasi berdistribusi normal.

\section{Uji Multikolinearitas}

Model regresi yang baik seharusnya tidak terjadi korelasi diantara variabel independen. Uji multikolinieritas dalam SPSS dilakukan dengan uji regresi, dengan nilai patokan VIF (Variance Inflation Factor) dan koefisien korelasi antar variabel bebas (Imam Ghozali, 2013:105). Pengujian Multikolinearitas akan menggunakan Variance Inflance Factor (VIF) dengan kriteria yaitu : Jika angka tolerance 0,10 dan VIF $>10$ dikatakan terdapat gejala multikolinearitas. 
Tabel 4.6

Hasil Uji Multikolinearitas

Coefficients $^{\mathrm{a}}$

\begin{tabular}{|c|c|c|c|c|c|c|c|}
\hline \multirow[b]{2}{*}{ Model } & \multicolumn{2}{|c|}{$\begin{array}{c}\text { Unstand } \\
\text { a rdized } \\
\text { Coefficie } \\
\text { nts }\end{array}$} & \multirow{2}{*}{$\begin{array}{c}\text { Standar } \\
\text { dized } \\
\text { Coeffic } \\
\mathrm{i} \\
\text { ents } \\
\\
\text { Beta }\end{array}$} & \multirow[b]{2}{*}{$\mathrm{t}$} & \multirow{2}{*}{ Sig } & \multicolumn{2}{|c|}{$\begin{array}{c}\text { Collinea } \\
\text { r ity } \\
\text { Statistics }\end{array}$} \\
\hline & B & $\begin{array}{l}\text { Std. } \\
\text { Error }\end{array}$ & & & & $\begin{array}{l}\text { Toler } \\
\text { ance }\end{array}$ & $\begin{array}{l}\text { VI } \\
\text { F }\end{array}$ \\
\hline 1 (Constant) & $\begin{array}{l}10 . \\
468\end{array}$ & $\begin{array}{r}6.1 \\
61\end{array}$ & & $\begin{array}{r}1.6 \\
99\end{array}$ & $\begin{array}{r}.09 \\
8\end{array}$ & & \\
\hline $\begin{array}{l}\text { Keadilan_Org } \\
\text { anisasi }\end{array}$ & $\begin{array}{r}.29 \\
2\end{array}$ & $\begin{array}{r}.30 \\
1\end{array}$ & .150 & $\begin{array}{r}.97 \\
0\end{array}$ & $\begin{array}{r}.33 \\
9\end{array}$ & $\begin{array}{r}.99 \\
9\end{array}$ & $\begin{array}{r}1.0 \\
01\end{array}$ \\
\hline Sistem_Penge & .52 & .24 & 321 & 2.1 & .04 & .99 & 1.0 \\
\hline ndalian Intern & 5 & 6 & .331 & 36 & 0 & 9 & 01 \\
\hline
\end{tabular}

a. Dependent Variable: Kecurangan

Sumber Data : Output SPSS, 2016

Dari tabel 4.6 di atas, diketahui bahwa nilai variance inflation factor (VIF) kedua variabel keadilan organisasi dan sistem pengendalian intern adalah lebih kecil dari 10 . Dan nilai tolerance lebih besar dari 0.1 sehingga dapat disimpulkan bahwa antar variabel independen tidak terjadi persoalan multikolineritas.

\section{Uji Heteroskedasitas}

Pengujian ini bertujuan untuk menguji apakah dalam model regresi terjadi ketidaksamaan variance dari residual satu pengamatan ke pengamatan yang lain. Berikut cara untuk mendeksi ada tidaknya heterokedasitas yaitu dengan melihat grafik plot antara nilai prediksi variabel terikat (dependen) yaitu ZPRED dengan residualnya SRESID. Deteksi ada tidaknya heterokedasitas dapat dilakukan dengan melihat ada tidaknya pola tertentu pada grafik scatterplot antara SRESID dan ZPRED dimana sumbu $\mathrm{Y}$ adalah $\mathrm{Y}$ yang telah diprediksi, dan sumbu $\mathrm{X}$ adalah residual (Y prediksi - Y sesungguhnya) yang telah di studentized.

\section{Gambar 4.1}

\section{Grafik Scatterplot}

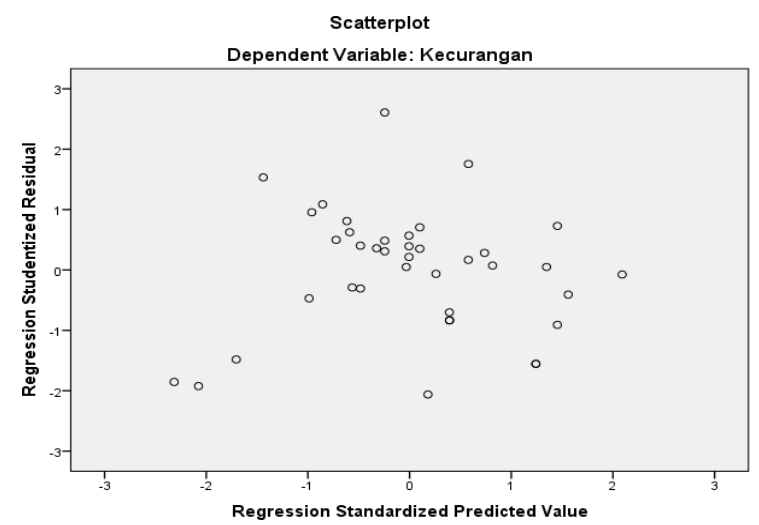

Sumber Data : Output SPSS, 2016 
Dari output gambar 4.1 di atas, dapat diketahui titik-titik tidak membentuk pola yang jelas, dan titik-titik menyebar di atas dan di bawah angka 0 pada sumbu Y. Jadi dapat disimpulkan bahwa tidak terjadi heteroskedasitas dalam model regresi, sehingga model regresi layak digunakan untuk memprediksi kecurangan berdasarkan variabel yang mempengaruhinya yaitu keadilan organisasi, dan pengendalian intern.

\section{Uji Auto Korelasi}

Pengujian ini bertujuan untuk menguji apakah dalam model regresi linear berganda ada korelasi antara kesalahan penganggu pada periode $t$ dengan kesalahan pada periode t-1 (sebelumnya). Jika terjadi korelasi, maka terjadi problem autokorelasi. model regresi yang baik adalah bebas dari autokorelasi, (Ghozli, 2013:110). Untuk mendeteksi ada tidaknya autokorelasi, melalui metode tabel Durbin-Watson secara umum dapat diambil patokan yaitu: Autokorelasi tidak terjadi bila nilai $\mathrm{D}-\mathrm{W}=2$. Autokorelasi positif terjadi jika D-W mendekati 0, sedangkan autokorelasi negatif terjadi bila D-W mendekati 4

\section{Tabel 4.7}

\section{Hasil Uji Auto Korelasi}

\begin{tabular}{|c|c|c|c|c|c|}
\hline & & \multicolumn{4}{|c|}{ Model Summary ${ }^{b}$} \\
\hline & $\mathrm{R}$ & $\begin{array}{c}\mathrm{R} \\
\text { Squa } \\
\mathrm{re}\end{array}$ & $\begin{array}{l}\text { Adju } \\
\mathrm{S} \text { ted } \\
\mathrm{R} \\
\mathrm{Squa} \\
\mathrm{r}\end{array}$ & $\begin{array}{c}\text { Std. } \\
\text { Error } \\
\text { of the } \\
\text { Estimat } \\
\text { e }\end{array}$ & $\begin{array}{c}\text { Dur } \\
\mathrm{b} \text { in- } \\
\text { Wat } \\
\mathrm{s} \\
\text { on }\end{array}$ \\
\hline 1 & $.367^{\mathrm{a}}$ & .135 & .086 & 5.731 & 1.829 \\
\hline
\end{tabular}

a. Predictors: (Constant),

Sistem_Pengendalian_Intern,

Keadilan_Organisasi

b. Dependent Variable:

Kecurangan Sumber Data : Output

SPSS, 2016

Berdasarkan tabel 4.7 statistic Durbiin Watson, dengan signifikansi 0.05 dan jumlah data $(\mathrm{n})=39$, serta $\mathrm{k}=2$ ( $\mathrm{k}$ adalah jumlah variabel independen) diperoleh nilai dL sebesar 1.382 dan dU sebesar 1.597. Dari hasil output di atas diperoleh nilai DW sebesar 1.829. Hal ini disimpulkan bahwa nilai DW atau 1.829 terletak diantar dU 1.597 dan 4-dU atau 2.403, sehingga hipotesis nol diterima yang berarti tidak ada autokorelasi

\section{Analisis Regresi Linear Berganda}

Berdasarkan hasil pengolahan yang dilakukan dengan bantuan Statistical

Package For The Sicial Science (SPSS) 22.0 for Windows diperoleh hasil koefisien regresi sebagai berikut :

$\mathrm{Y}=\alpha+\beta 1 \mathrm{X} 1+\beta 2 \mathrm{X} 2+\varepsilon$

$\mathrm{Y}=10.468+0.150 \mathrm{X} 1+0.331 \mathrm{X} 2+\varepsilon$

Dari persamaan di atas dapat dijelaskan sebagai berikut :

a. Konstanta sebesar 10.468, artinya jika variabel keadilan organisasi (X1) dan sistem pengendalian intern (X2) adalah 0, maka nilai tingkat Kecurangan (Y) akan sebesar 10.468 . 
b. Nilai koefesien regresi variabel keadilan organisasi (X1), yaitu sebesar 0.150 dengan tingkat signifikan $0.339>0.05$, sehingga keadilan organisasi tidak berpengaruh terhadap kecurangan, artinya tidak terjadi peningkatan pada tingkat kecurangan.

c. Nilai koefisien regresi variabel sistem pengendalian intern (X2), yaitu sebesar 0.331 dengan tingkat signifikan $0.040<0.05$, sehingga berpengaruh positif, artinya setiap peningkatan sistem pengendalian intern sebesar 1 , maka terjadi peningkatan tingkat kecurangan sebesar 0.331 .

\section{Pengujian Hipotesis}

Untuk mengetahui ada tidaknya pengaruh antara variabel keadilan organisasi dan sistem pengendalian intern terhadap kecurangan secara parsial, maka dapat dilakukan dengan cara sebagai berikut :

\section{Uji hipotesis secara parsial (Uji t)}

Uji parsial t digunakan untuk mengetahui pengaruh masing-masing variabel independen terhadap variabel dependen, dengan kriteria sebagai berikut : (1) Jika $p$ value $<0,05$ maka Ho ditolak. (2) Jika $\mathrm{p}$ value $>0,05$ maka Ho diterima. Peneliti melakukan pengujian hipotesis secara parsial masing-masing variabel penelitian yaitu sebagai berikut :

1. Keadilan Organisasi (X1) terhadap Kecurangan (Y) Hipotesis penelitian yang akan diuji adalah sebagai berikut

Ho1 : Diduga tidak terdapat pengaruh keadilan organisasi terhadap kecurangan Hal : Diduga terdapat pengaruh keadilan organisasi terhadap kecurangan

Pada tabel 4.8 coefficients diperoleh thitung variabel keadilan organisasi sebesar 0.970 dengan tingkat signifikansi 0.339 . Dengan menggunakan batas signifikan 0.05 nilai signifikan tersebut berada di atas taraf 5\%, yang berarti Ho diterima dan $\mathrm{Ha}$ ditolak, artinya keadilan organisasi tidak berpengaruh secara signifikan terhadap kecurangan.

\section{Tabel 4.8.}

Uji Hipotesis Parisal (uji t) Coefficients $^{\mathrm{a}}$

\begin{tabular}{|c|c|c|c|c|c|}
\hline \multirow[b]{2}{*}{ Model } & \multicolumn{2}{|c|}{$\begin{array}{c}\text { Unstand } \\
\text { a rdized } \\
\text { Coefficie } \\
\text { nts }\end{array}$} & \multirow{2}{*}{$\begin{array}{c}\text { Standa } \\
\text { rdized } \\
\text { Coeffi } \\
\text { cients } \\
\text { Beta }\end{array}$} & \multirow[b]{2}{*}{$\mathrm{t}$} & \multirow[b]{2}{*}{$\begin{array}{c}\text { Sig } \\
\text {. }\end{array}$} \\
\hline & $\mathrm{B}$ & \begin{tabular}{|l} 
Std. \\
Erro \\
$\mathrm{r}$ \\
\end{tabular} & & & \\
\hline 1 (Constant) & $\begin{array}{r}10 . \\
46 \\
8\end{array}$ & $\begin{array}{r}6.1 \\
61\end{array}$ & & $\begin{array}{r}1.6 \\
99\end{array}$ & $\begin{array}{r}.09 \\
8\end{array}$ \\
\hline Keadilan_. & .29 & .30 & & .97 & .33 \\
\hline Organisasi & 2 & 1 & .150 & 0 & 9 \\
\hline Sistem_Pe & .52 & .24 & & 2.1 & .04 \\
\hline ng Intern & 5 & 6 & .331 & 36 & 0 \\
\hline
\end{tabular}

a. Dependent Variable: Kecurangan 
Sumber: output SPSS 
Hasil Penelitian ini menunjukkan bahwa keadilan organisasi tidak berpengaruh terhadap kecurangan yang terjadi pada PT. Bank X. Hal ini dikarenakan hasil pengujian keadilan organisasi menunjukkan bahwa nilai sig $>0.05$ atau sebesar 0.339 . Hal ini dapat disimpulkan bahwa tingkat keadilan organisasi pada PT. Bank X yang cukup baik sehingga tidak mempengaruhi terjadinya kecurangan pada PT. Bank X. Hasil penelitian ini tidak konsisten dengan hasil penelitian sebelumnya, yaitu penelitian yang dilakukan oleh Lisa Amelia dan Herman (2008) menyatakan bahwa keadilan organisasi berpengaruh signifikan negatif terhadap kecurangan.

2. Sistem Pengendalian Intern (X2) terhadap Kecurangan (Y)

Hipotesis penelitian yang akan diuji adalah sebagai berikut

Ho2 : Diduga tidak terdapat pengaruh sistem pengendalian intern terhadapkecurangan

$\mathrm{Ha} 2$ : Diduga terdapat pengaruh sistem pengendalian intern terhadap kecurangan

Pada tabel 4.8. coefficients diperoleh thitung variabel sistem pengendalian intern sebesar 2.136 dengan tingkat signifikansi 0.040. Dengan menggunakan batas signifikan 0.05 nilai signifikan tersebut berada di bawah taraf 5\%, yang berarti Ho ditolak dan Ha diterima, artinya sistem pengendalian intern berpengaruh secara signifikan terhadap kecurangan. Hal ini dapat disimpulkan bahwa semakin baik penerapan sistem pengendalian intern maka tingkat terjadinya kecurangan akan semakin rendah. Hasil penelitian ini konsisten dengan hasil penelitian yang sebelumnya, yaitu penelitian yang dilakukan oleh Lisa Amelia Herman (2008) menyatakan bahwa sistem pengendalian intern memiliki pengaruh yang signifikan terhadap terjadinya kecurangan.

\section{PENUTUP}

\section{Kesimpulan}

Adapun kesimpulan yang dapat ditarik dari penelitian ini adalah sebagai berikut:

1. Keadilan organisasi tidak berpengaruh secara signifikan terhadap kecurangan.

2. Sistem pengendalian intern memiliki pengaruh yang signifikan terhadap kecurangan.

\section{Saran}

Beberapa saran yang dapat diberikan adalah sebagai berikut:

1. Penelitian selanjutnya lebih memperbanyak responden dalam penelitian.

2. Peneliti menyarankan agar mengembangkan penelitian dengan menambahkan faktorfaktor dan variabel lain diluar model penelitian, seperti gaya kepemimpinan dan kualitas sumber daya manusia (SDM) ini untu menambah daftar penelitian yang mungkin mempunyai pengaruh terhadap kecurangan.

3. Waktu penelitian untuk responden pada pegawai bank sebaiknya jangan dilakukan dalam kurun waktu Desember sampai dengan Januari karena dalam kurun waktu tersebut merupakan waktu sibuk bagi pegawai bank untuk melakukan tutup buku akhir tahun. 


\section{DAFTAR PUSTAKA}

Bagia I Wayan. Perilaku Organisasi. Yogyakarta : Graha Ilmu. 2015.

Bodnar George H., William S. Hopwood. 2000. Sistem Informasi Akuntansi, Jakarta : Salemba Empat.

Ghozali, Imam, 2005. Aplikasi Analisis Multivariate dengan Program SPSS. Semarang : Badan Penerbit Universitas Diponegoro Semarang, 2005.

Herman, Lisa Amelia. 2013. Pengaruh Keadilan Organisasi dan Sistem Pengendalian Intern Terhadap Kecurangan. Jurnal Akuntansi Volume 1/ Nomor 1/ Tahun 2013. Fakultas Ekonomi Universitas Negeri Padang.

Hesti Arlich Arifiyani. 2012. Pengaruh Pengendalian Intern, Kepatuhan dan Kompensasi Manajemen Terhadap Perilaku Etis Karyawan. Jurnal Nominal/ Volume I Nomor 1/ Tahun 2012. Fakultas Ekonomi Universitas Negeri Yogyakarta.

H.M. Jogiyanto. 1988. Sistem Informasi Akuntansi, Jakarta : BPFE-Yogyakarta.

Ikatan Bankir Indonesia (IBI). Manajemen Risiko 3. Jakarta : PT. Gramedia

PustakaUtama, 2015.

Ikatan Bankir Indonesia (IBI). Manajemen Risiko 2. Jakarta : PT. Gramedia Pustaka Utama, 2015.

Ivancevich John M.,dkk. Perilaku dan Manajemen Organisasi. Indonesia : Erlangga. 2006.

Mulyadi. 2002. Auditing. Buku 1. Jakarta : Salemba Empat.

Mulyadi Deddy. Perilaku Organisasi dan Kepemimpinan Pelayanan. Bandung :

Alfabeta. 2015

Priantara Diaz. Fraud Auditing \& Investigation. Jakarta : Mitra Wacana Media. 2014.

Romney Marshall B., Paul John Steinbart. 2006. Accounting Information System, Edisi Sembilan.Jakarta: Salemba Empat.

Sukirman, Maylia Parmono Sari. Model deteksi kecurangan berbasis fraud triangle. Jurnal Akuntansi \& Auditing Volume 9/Nomor 2/Mei 2013. Universitas Negeri Semarang.

Tuannakotta, Theodorus M. Akuntansi Forensik \& Audit Investigatif. Jakarta : Salemba Empat.

Tunggal, Amin Widjaja. Internal Auditing. Jakarta : Harvarindo, 2001. 